\title{
U-PB ZIRCON AGES FROM BEDROCK SAMPLES COLLECTED IN THE TANACROSS D- 1, AND PARTS OF D-2, C-1, AND C-2 QUADRANGLES, ALASKA
}

Alicja Wypych, James V. Jones III, and Paul O'Sullivan

\section{Preliminary Interpretive Report 2020-2}

This publication is PRELIMINARY in nature and meant to allow rapid release of field observations or initial interpretations of geology or analytical data. It has undergone limited peer review but does not necessarily conform to DGGS editorial standards. Interpretations or conclusions contained in this publication are subject to change.

2020

STATE OF ALASKA

DEPARTMENT OF NATURAL RESOURCES

DIVISION OF GEOLOGICAL \& GEOPHYSICAL SURVEYS
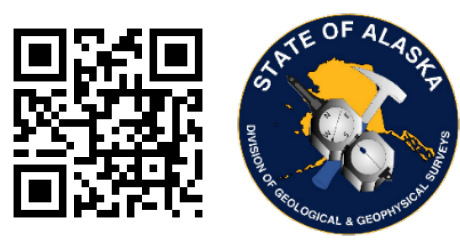


\section{STATE OF ALASKA}

Mike Dunleavy, Governor

\section{DEPARTMENT OF NATURAL RESOURCES}

Corri A. Feige, Commissioner

\section{DIVISION OF GEOLOGICAL \& GEOPHYSICAL SURVEYS}

Steve Masterman, State Geologist \& Director

Publications produced by the Division of Geological \& Geophysical Surveys are available to download from the DGGS website (dggs.alaska.gov). Publications on hard-copy or digital media can be examined or purchased in the Fairbanks office:

\section{Alaska Division of Geological \& Geophysical Surveys (DGGS)}

3354 College Road | Fairbanks, Alaska 99709-3707

Phone: 907.451 .5010 | Fax 907.451.5050

dggspubs@alaska.gov $\mid$ dggs.alaska.gov

\section{DGGS publications are also available at:}

Alaska State Library, Historical

Collections \& Talking Book Center

395 Whittier Street

Juneau, Alaska 99801

Alaska Resource Library and

Information Services (ARLIS)

3150 C Street, Suite 100

Anchorage, Alaska 99503

\section{Suggested citation:}

Wypych, Alicja, Jones, J.V., III, and O'Sullivan, Paul, 2020, U-Pb Zircon ages from bedrock samples collected in the Tanacross D-1, and parts of the D-2, C-1, and C-2 quadrangles, Alaska: Alaska Division of Geological \& Geophysical Surveys Preliminary Interpretive Report 2020-2, 20 p. http://doi.org/10.14509/30465
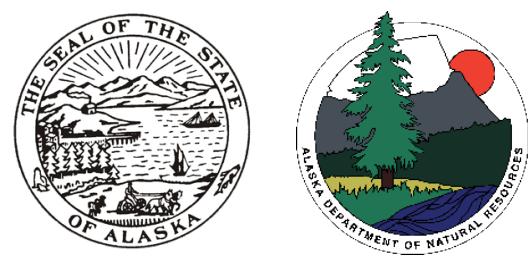


\section{U-PB ZIRCON AGES FROM BEDROCK SAMPLES COLLECTED INTHE TANACROSS D- 1, AND PARTS OF D-2, C-1, AND C-2 QUADRANGLES, ALASKA \\ Alicja Wypych ${ }^{1}$, James V. Jones III', and Paul O'Sullivan ${ }^{3}$}

\section{INTRODUCTION}

This Alaska Division of Geological \& Geophysical Surveys (DGGS) Preliminary Interpretive Report presents $\mathrm{U}-\mathrm{Pb}$ ages of zircons from 14 sedimentary, metamorphic, and igneous samples collected during 2017 and 2018 field investigations in the northeastern Tanacross quadrangle, Alaska. The DGGS Northeast Tanacross project is part of a multi-year effort to investigate the geology and mineral-resource potential of the Yukon-Tanana Upland region in collaboration with the U.S. Geological Survey. The purpose of the U-Pb isotopic study is to better understand the Devonian to Mississippian and Mesozoic to early Paleogene episodes of magmatic and tectonic events within the Yukon-Tanana Upland and the relationship of magmatism to the metallic mineral deposits.

This area is characterized by the presence of two Late Devonian to Mississippian metamorphic assemblages-Lake George and Fortymile River (Dusel-Bacon and others, 2006; Foster, 1970). Both assemblages are composed of metasedimentary and metavolcanic rocks that have been intruded by Devonian to Eocene intrusive rocks of varying composition and texture. Paleozoic intrusive rocks are deformed and metamorphosed and include prevalent Late Devonian-Early Mississippian augen orthogneiss, herein called the Divide Mountain suite, that was emplaced into and deformed together with the Lake George assemblage (Aleinikoff and others, 1986). The Fortymile River assemblage is primarily crosscut by Mississippian to Permian intrusive rocks that are also pervasively deformed and metamorphosed. Following Jurassic to middle Cretaceous regional metamorphism and deformation, all metamorphic rock packages were intruded by middle to Late Cretaceous volcanic and plutonic rocks (Naibert and others, 2018), some of which have known or suspected potential for gold together with silver, zinc, copper, and lead mineralization.

Products included in this data release include a summary of sample-collection methods, the laboratory report, analytical data tables, and associated metadata. All components of this data release are available on the DGGS http://doi.org/10.14509/30465.

\section{ANALYTICAL METHODS}

Zircon grains from three amphibolite samples (18AW074, 18TJN213, and 18JEA011) were extracted using Electro Pulse Disaggregator by Zirchron LLC (Tucson, AZ) following the method described in Todd and others (2019). Zircon grains from the remaining eleven samples were extracted the GeoSep Services laboratory following the detailed description of Donelick and others (2005). Each sample was crushed using a jaw crusher to $<5 \mathrm{~mm}$, the crushate was sieved using 300-micron nylon mesh, the $<300$-micron fraction was washed with tap water and air-dried at room temperature, and zircon was isolated using standard gravimetric and magnetic mineral separation techniques.

\footnotetext{
${ }^{1}$ Alaska Division of Geological \& Geophysical Surveys, 3354 College Road, Fairbanks, AK 99709

${ }^{2}$ U.S. Geological Survey, Alaska Science Center, 4210 University Dr., Anchorage, AK 99508

${ }^{3}$ GeoSep Services, 1521 Pine Cone Road, Moscow, ID 83843
} 
Zircon grains were mounted in epoxide resin and polished to a fine finish using 0.3-micron alumina slurry. Zircon grain mounts were stirred vigorously in reagent grade 5.5 molar nitric acid for 20 seconds at $21^{\circ} \mathrm{C}$ and rinsed with distilled water to remove any common lead contamination. Grains, and the locations for laser spots on these grains, were selected for analysis from all sizes and morphologies present using transmitted light with an optical microscope at a magnification of 2000x. This approach is preferred over the use of cathodoluminescence (CL) two-dimensional imaging as it allows the recognition and characterization of features below the surface of individual grains, including the presence of inclusions and the orientation of cracks, which may result in spurious isotopic counts. Furthermore, because of the relatively small grain-sizes present in some analyzed samples, CL imaging would not have contributed useful information on zoning within grains as the location on each grain for analysis was constrained by whether or not the grain was simply large enough to allow a spot analysis.

Data were collected for the following isotopic masses: ${ }^{202} \mathrm{Hg},{ }^{204} \mathrm{Hg}+{ }^{204} \mathrm{~Pb},{ }^{206} \mathrm{~Pb},{ }^{207} \mathrm{~Pb},{ }^{208} \mathrm{~Pb},{ }^{232} \mathrm{Th}$, ${ }^{235} \mathrm{U}$, and ${ }^{238} \mathrm{U}$ ( 250 data scans over 30 seconds) followed by ${ }^{28} \mathrm{Si}$ and ${ }^{91} \mathrm{Zr}$ ( 5 data scans over 4 seconds). The instruments used were a New Wave YAG 213-nm laser ablation (LA) system in line with a Finnigan Element2 magnetic sector, inductively coupled plasma, mass spectrometer (ICP-MS) at the Washington State University Geoanalytical Laboratory in Pullman, Washington (Chang and others, 2006). All analyses were performed using a $20-\mu \mathrm{m}$ spot. Following approximately 6 seconds of background data collection, laser ablation commenced, and data were collected for the ablated material. Ablated material was transported to the plasma line using He; Ar was the plasma gas.

Zircon standards for which independently accepted ages are published were designated as primary, secondary, and tertiary for purposes of $\mathrm{U}-\mathrm{Pb}$ age calibration (see table 1). Two primary and two secondary standard spots were analyzed before and following each group of $~ 25-30$ tertiary standards and/or unknown sample spots. Five spots of each tertiary standard were analyzed near the beginning and again near the end of the session.

Table 1.Zircon standards used during the analysis.

\begin{tabular}{|l|l|l|l|}
\hline Standard & Standard & U-Pb age $\mathbf{( \pm 2} \sigma)$ & Reference \\
\hline FC & Duluth Complex & $1099.0 \pm 0.6 \mathrm{Ma}$ & Paces and Miller, 1993 \\
\hline F5 & Duluth Complex & $\begin{array}{l}1099.0 \pm 0.6 \mathrm{Ma} \\
\text { (assumed equal to FC-1) }\end{array}$ & Paces and Miller, 1993 \\
\hline IF & Fish Canyon Tuff & $28.201 \pm 0.012 \mathrm{Ma}$ & $\begin{array}{l}\text { Kuiper and others, 2008; } \\
\text { Lanphere and Baadsgaard, 2001 }\end{array}$ \\
\hline MD & Mount Dromedary & $99.12 \pm 0.14 \mathrm{Ma}$ & Renne and others, 1998 \\
\hline PX & Peixe & $563.5 \pm 1.6 \mathrm{Ma}$ & Gehrels and others, 2008 \\
\hline R3 & Braintree complex & $418.9 \pm 0.4 \mathrm{Ma}$ & Black and others, 2004 \\
\hline T2 & $\begin{array}{l}\text { Temora 2, Middledale } \\
\text { gabbroic diorite }\end{array}$ & $416.78 \pm 0.33 \mathrm{Ma}$ & Black and others, 2004 \\
\hline TR & Tardree Rhyolite & $61.23 \pm 0.11 \mathrm{Ma}$ & Dave Chew, written communication, undated \\
\hline
\end{tabular}

Data Modeling - Previous LA-ICP-MS studies of U-Pb zircon dating deployed the so-called intercept method which assumes that isotopic ratios vary linearly with scan number due solely to linearly varying isotopic fractionation (Chang and others, 2006; Gehrels and others, 2008). For the intercept method, a line is 
fitted to background-corrected isotopic ratio (that is, ${ }^{206} \mathrm{~Pb} /{ }^{238} \mathrm{U}$ ) versus data-scan number and the intercept of the fitted line (corresponding to data scan number $=0$ ) is used as the isotopic ratio for age calculation, and the error on the intercept is used for age error calculation. For this study, individual isotopes were modeled by fitting a sum of 10 Gaussian equations to the raw signal data (not background corrected) using chi-squared minimization. Two fitting passes were performed: After the first pass, all raw-signal values greater than two standard deviations $(2 \sigma)$ away from the sum of fitted Gaussians were designated outliers; the second pass fit the sum of Gaussians to the data excluding the outliers. The advantage of the present approach is that it avoids the assumption of linearly varying isotopic ratio with scan number, an assumption easily violated for zircons that may contain useful information (for example, a zircon for which the ablation pit variably penetrates two zones having different $\mathrm{U}-\mathrm{Pb}$ ages).

Measured background values for each isotope at each LA-ICP-MS spot were calculated as follows: A) the final background scan was assigned as the scan closest to the global minima ${ }^{232} \mathrm{Th}$ and ${ }^{238} \mathrm{U}$ values; if no such global minima were found, the analysis was deemed a failure; B) a line was fitted to the background values, outliers identified, and a line again fitted to the data excluding the outliers; C) for a fitted line exhibiting a negative slope (indicative of a decaying background), the value of the line at the last background scan was assigned as the background value; for a fitted line exhibiting a zero or positive slope, the mean value of the data excluding the outliers was assigned as the background value; and D) the error of the background value was set equal to the standard deviation of the all background values (excluding outliers) about their fitted line (negative slope) or mean (zero or positive slope).

Session-wide fitted background values for each isotope were determined using all zircon standards and applied to all spots in the session. These steps were taken for each isotope: A) measured background value versus spot number in the session was fitted to a $3^{\text {rd }}$-order polynomial, outliers identified, and the fitting repeated excluding the outliers, and B) fitted background at each session spot was calculated using the $3^{\text {rd }}$ order polynomial. Session-wide fitted background error was set equal to the standard deviation of the measured background values (excluding outliers) about their respective fitted $3^{\text {rd }}$-order polynomial. For any spot (standard or unknown) where the measured background value exceeded the session-wide fitted value by more than $2 \sigma$, the background error was set equal to $1 \sigma$ plus one half of the amount by which the measured background value exceeded the session-wide fitted value by $2 \sigma$.

The sum of fitted Gaussians was used here primarily to identify outlier data and characterize signal noise. After the second fitting pass, the standard deviation of the non-outlier data about the respective sum of fitted Gaussians was taken as the absolute signal error for each data scan. When $\mathrm{N}$ data scans contribute to a single isotopic signal value used for age calculation (only concordant scans when the number of concordant data scans are greater than zero; all data scans for common $\mathrm{Pb}$-correction based on isotopic sums), the error of the single isotopic signal value was set equal to the product of $\mathrm{A}) \mathrm{N}^{1 / 2}$ and $\mathrm{B}$ ) the absolute signal error for each data scan.

$\mathbf{P b} / \mathbf{U}$ Fractionation Factor-Fractionation factors were determined for each data scan of each primary standard spot. For a particular isotopic ratio (for example, ${ }^{206} \mathrm{~Pb} /{ }^{238} \mathrm{U}$ ), the fractionation factor as used here equals the accepted isotopic ratio divided by the measured ratio. A two-dimensional grid (spot number, scan number) of fractionation factors for each isotopic ratio was constructed for the session as a whole by fitting a 
series of $4^{\text {th }}$-order polynomials (excluding outliers). Under the operating conditions of the LA-ICP-MS sessions in this study, fractionation factors were found to vary strongly with scan number, decreasing with increasing scan number (presumably due to increasing ablation pit depth and the effect this had on fractionation [for example, Paton and others, 2010]).

Fractionation factors were calculated using isotopic values based on the sum of fitted Gaussians. Ages, including when the standards were treated as unknowns, were calculated using raw isotopic signal values (excluding outliers) to avoid any bias due to artifacts of the fitting of the sum of Gaussians.

Fractionation Factor Adjustment for Integrated $\alpha$-damage-Zircon is widely known to accumulate $\alpha$ radiation damage (Zhang and others, 2009). It is assumed here that increased $\alpha$-damage in a zircon leads to a decrease in the hardness of the zircon; this in turn leads to a faster rate of laser penetration into the zircon during ablation leading to a shift in isotopic fractionation. Ages calculated for the primary, secondary, and tertiary zircon standards, when those standards were treated as unknowns, were used to construct a fractionation factor correction curve (exponential form). The notion of matrix-matched standard and unknown zircons has been proposed largely based on trace element chemistry (Black and others, 2004). Here, time and crystallographic damage, parameters invisible to instruments used to characterize trace element chemistry, were introduced and applied in conjunction with $\mathrm{U}$ and Th chemistry.

Common Pb Correction-Common $\mathrm{Pb}$ was subtracted out using the Stacey and Kramers (1975) common $\mathrm{Pb}$ model for Earth. Ages and common $\mathrm{Pb}$ ratio were determined iteratively using a preset, sessionwide minimum common $\mathrm{Pb}$ age value (default for each session was the age of the oldest age standard which was 1,099 Ma FC-1 and/or FC-5z).

Preferred Age-Uranium decay constants and the ${ }^{238} \mathrm{U} /{ }^{235} \mathrm{U}$ isotopic ratio reported in Steiger and Jäger (1977) were used in this study. ${ }^{207} \mathrm{~Pb} /{ }^{235} \mathrm{U}_{\mathrm{c}}\left({ }^{235} \mathrm{U}_{\mathrm{c}}=137.88^{238} \mathrm{U}\right),{ }^{206} \mathrm{~Pb} /{ }^{238} \mathrm{U}$, and ${ }^{207} \mathrm{~Pb} /{ }^{206} \mathrm{~Pb}$ ages were calculated for each data scan and checked for concordance; concordance here was defined as overlap of all three ages at the $1 \sigma$ level (the use of the $2 \sigma$ level was found to skew the results to include scans with significant common $\mathrm{Pb}$ ). The background-corrected isotopic sums of each isotope were calculated for all concordant scans. The precision of each isotopic ratio was calculated by using the background and signal errors for both isotopes. The fractionation factor for each data scan, corrected for the effect of accumulated $\alpha$-damage, was weighted according to the ${ }^{238} \mathrm{U}$ or ${ }^{232} \mathrm{Th}$ signal value for that data scan; an overall weighted mean fractionation factor for all concordant data scans was used for the final age calculation.

If the number of concordant data scans for a spot was greater than zero, then either the ${ }^{206} \mathrm{~Pb} /{ }^{238} \mathrm{U}$ or ${ }^{207} \mathrm{~Pb} /{ }^{206} \mathrm{~Pb}$ age was chosen as the preferred age, whichever exhibited the lower relative error. If zero concordant data scans were observed, then the common $\mathrm{Pb}$-corrected age based on isotopic sums of all acceptable scans was chosen as the preferred age. Common $\mathrm{Pb}$ was subtracted out using the Stacey and Kramers (1975) common $\mathrm{Pb}$ model for Earth. Ages and common $\mathrm{Pb}$ ratio were determined iteratively using a preset, sessionwide minimum common $\mathrm{Pb}$ age value (default for each session was the age of the oldest age standard which was 1,099 Ma FC-1 and/or FC-5z).

Data from all spot analyses are shown in the detailed tables that accompany this report. In addition to the reported "preferred age" defined above (i.e., either ${ }^{206} \mathrm{~Pb} /{ }^{238} \mathrm{U}$ age, ${ }^{207} \mathrm{~Pb} /{ }^{206} \mathrm{~Pb}$ age, or common $\mathrm{Pb}$-corrected age), we also calculated the Concordia age (including decay constant uncertainties) for each grain analyzed. 
The Concordia age makes optimum use of both decay schemes and obviates the need to choose an arbitrary age threshold for selecting ${ }^{206} \mathrm{~Pb} /{ }^{238} \mathrm{U}$ or ${ }^{207} \mathrm{~Pb} /{ }^{206} \mathrm{~Pb}$ age as the "preferred age" for an individual grain (Ludwig, 2012; Nemchin and Cawood, 2005). Additionally, the Concordia age calculation gives the probability of concordance (POC) for each analysis, which provides a useful means of assessing concordance for all grains regardless of age. After calculating the Concordia age and associated statistics for each analysis, we screened the data for uncertainty and POC. Analyses with greater than 10 percent age uncertainty (at 1 sigma) were excluded or "filtered" from plots and statistical treatments. Grains with $\mathrm{POC}<0.1$ were also excluded unless the grain was older than $1,000 \mathrm{Ma}$ and had a calculated concordance (comparison of ${ }^{206} \mathrm{~Pb} /{ }^{238} \mathrm{~Pb}$ and ${ }^{207} \mathrm{~Pb} /{ }^{206} \mathrm{~Pb}$ ages) between 80 percent and 105 percent. Data that were filtered are included in the detailed data tables but are labeled as "filtered."

For metaigneous and igneous samples containing complex age distributions, grains contributing to the youngest "main" population of a sample (that is, those that are most likely contemporaneous with the crystallization of the host rock) are distinguished from "inherited" grains that are interpreted to represent xenocrysts from an older igneous or metamorphic zircon-forming event (Figs. 1-7). Calculated weightedmean ages and associated uncertainty $(2 \sigma)$ for each sample were determined using Isoplot 4.15 (Ludwig, 2012) and are shown in Table 2 and the summary table included with the data tables (pir2002-2-age-summarytable.xls). The data summary table (pir2002-2-age-summary-table.xls) shows only the preferred age calculated for the "main" population. Representative "main" or "inheritance" values in table 2 are only shown for populations with $\geq 2$ grains. Grains that were excluded from calculated ages because of interpreted inheritance or lead loss are shown with blue bars in figures 8-11 and are labeled as "excluded" in the detailed data tables.

For metasedimentary samples, detrital zircon age populations were calculated using the AgePick macro for Microsoft Excel (Gehrels, 2009), and results for those samples are shown in the inset tables in figures 9 and 11.

\section{SAMPLE DESCRIPTIONS}

Metamorphic bedrock samples analyzed from the Lake George assemblage include two mafic rocksone amphibolite and one coarser-grained metagabbro (18AW074 and 18TJN213, respectively). Metamorphic samples from the Fortymile River assemblage include quartzite from the Lake GeorgeFortymile River assemblage boundary region (17ET027), an amphibolite (18JEA011), a granitic orthogneiss (18ET395), and a quartzite from the northwest corner of the map area (18AW278). Igneous samples include two samples that crosscut the Fortymile River assemblage (18AW241 and 18MBW295) and four samples that were emplaced into the Lake George assemblage (18AW153, 18ET210, 17AW013, and 18RN293). We also report detrital zircon ages for two samples of Cretaceous to Paleocene sedimentary rocks (18ET382 and 18ET413) deposited in localized basins within the Fortymile River assemblage. 


\section{Lake George assemblage}

\section{$18 A W 074$}

Amphibolite; dark green, weathering brown; foliated, gneissic, grain size: $3 \mathrm{~mm}$; mineral assemblage: 65 percent amphibole, 30 percent feldspar, and 5 percent titanite. Sub- to anhedral hornblende crystals are fragmented, resorbed, with bluish actinolite replacing zones of hornblende, signifying possible retrograde metamorphism. Resorbed anhedral feldspars ( $3 \mathrm{~mm}$ long) have some polysynthetic zoning characteristics of plagioclase and are up to 80 percent sericitized. They are intergrown with amphibole. Sub- to euhedral titanite is associated with amphiboles and ranges in size from 0.1 to $0.5 \mathrm{~mm}$. Veins (1-7 mm thick) of feldspar and quartz(?) cut through the outcrop at this locality.

\section{TJN213}

Foliated metagabbro; green; banded; mineral assemblage: 30 percent hornblende, 20 percent augite, 20 percent orthopyroxene, 20 percent plagioclase, and 10 percent pigeonite. Small, about 0.2- to 0.3-mm hornblende crystals form aggregates in the rock. Resorbed, anhedral, about 0.5-mm-long plagioclase have polysynthetic twinning. Anhedral, resorbed augite is usually less than 0.5 - $\mathrm{mm}$ long, with common twinning and inclusions of feldspar(?). Similar to the clinopyroxene, the orthopyroxene is resorbed, with feldspar inclusions and averaging about $0.5 \mathrm{~mm}$ in size. Anhedral and partially resorbed pigeonite is associated with orthopyroxenes. The sample is equigranular, with about 1-cm-thick aggregates of small hornblende crystals in a matrix of pyroxene and feldspar (fig. 1). The aggregates seem to be elongated and form irregular layers or boudin-like layers. In outcrop, the rock has alternating layers of 1- to 3-mm-thick bands of amphibole-rich and feldspar-rich material interlayered with a fine-grained mix of amphibole and feldspar.
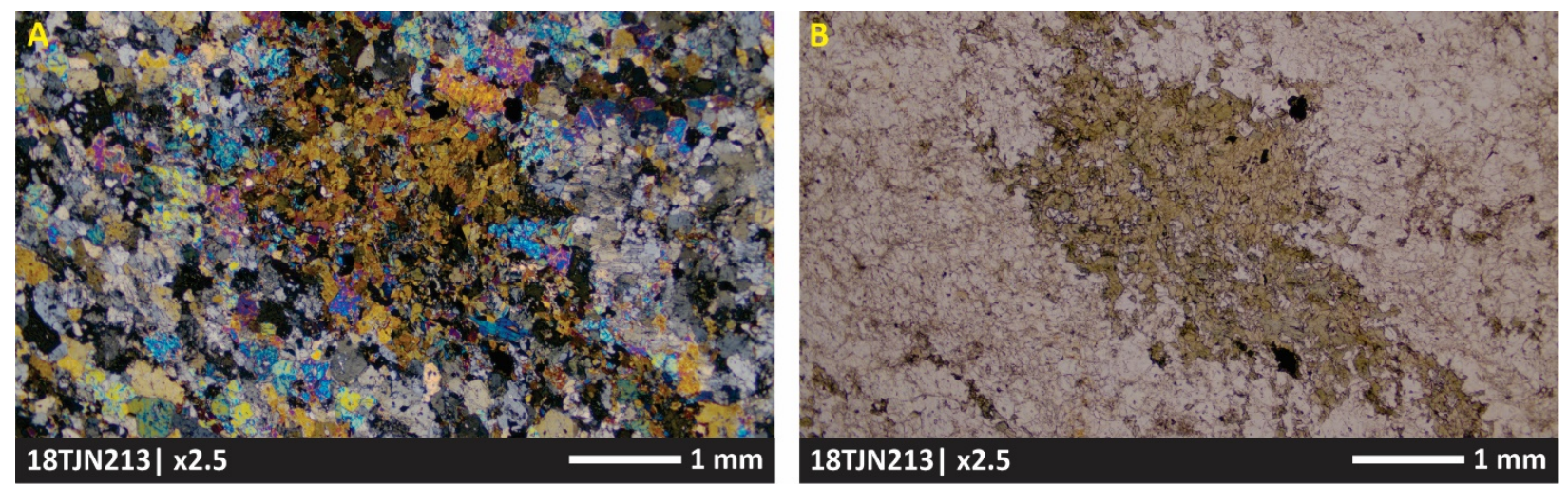

Figure 1. Transmitted-light photomicrographs of metagabbro from Lake George assemblage, A - crossed-polarized light, B plane light. The photograph illustrates a fine-grained amphibole aggregate in pyroxene and feldspar matrix. 


\section{Fortymile River assemblage}

\section{ET027}

Quartzo-feldspathic schist to gneiss; medium gray to tan; banded, schistose to gneissic, porphyroblastic, grain size: 0.2 to $0.5 \mathrm{~mm}$; mineral assemblage: 85 percent quartz, 5 percent white mica, 5 percent biotite, 3 percent plagioclase, 2 percent garnet, accessory epidote, accessory opaque minerals. Up to 0.5 -mm diameter, subhedral to anhedral garnet porphyroblasts are skeletal, often stretched and form augens. The garnet has quartz inclusions and quartz and secondary biotite in the strain shadows. The garnets are often surrounded by recrystallized, up to $0.8-\mathrm{mm}$, anhedral plagioclase, which are variably sericitized and calcite is present on fractures. The 0.2- to 0.6-mm-diameter anhedral quartz crystals, and rare feldspar form thin, irregular, about $0.5-\mathrm{mm}$-thick layers. Biotite is thin, up to 1-mm long, with bird's eye extinction. Some of the biotite is replaced by muscovite. Up to 1-mm-long muscovite with biotite form single-crystal-thick, irregular layers, defines foliation, and is parted by the quartzose layers. Local gneissic texture with 1 - to $20-\mathrm{cm}$-thick layers of quartz with thin interlayers of mica, including minor biotite, possible garnet, and likely a little chlorite are observed. To obtain enough material for dating, this sample has been combined from four samples: 17ET027, 17ET028, 17ET030, and 17ET032. The samples were collected along 0.8-mile transect.

\section{JEA011}

Garnet-bearing amphibolite; gray, grain size: 1 to $2 \mathrm{~mm}$; mineral assemblage: 50 percent hornblende, 49 percent plagioclase, and 1 percent garnet. Similar to 17ET027, this sample is a composite of multiple hand samples: 18JEA011, 18JEA013, 18JEA014, 18JEA015, 18RN330, and 18RN331, and was collected along 0.8mile transect.

\section{$18 E T 395$}

Orthogneiss; medium gray; interlayered, gneissic, grain size: 0.2 to $1 \mathrm{~mm}$; mineral assemblage: 50 percent quartz, 30 percent biotite, 15 percent plagioclase, 5 percent amphibole, accessory muscovite and epidote. Anhedral, up to $0.2-\mathrm{mm}$-diameter quartz crystals, with undulose extinction and small, up to 0.2-mm plagioclase crystals form thin, less than $0.3-\mathrm{mm}$, irregular felsic layers. The plagioclase is anhedral, slightly sericitized, and has polysynthetic twinning. Small, up to $0.5-\mathrm{mm}$-long biotite crystals highlight foliation in the rock but do not form regular, continuous layers (fig. 2A). Large, rotated, up to 2-mm porphyroclasts of either hornblende or actinolite are sub- to euhedral, with greenish-blue pleochroic colors, and some slight biotite and chlorite alteration (fig. $2 \mathrm{~B}$ ). The rock has some biotite-rich zones and more quartzose layers. In thin section, the quartzose zones make up most of the $1.5-\mathrm{cm}$ width, whereas the biotite-rich zone forms about a 5-mm-thick zone. On outcrop scale, boudins are observed.

This sample is a composite of 18ET395, 18ET396, and 18ET397 hand samples, which were collected over 0.2 -mile transect. 

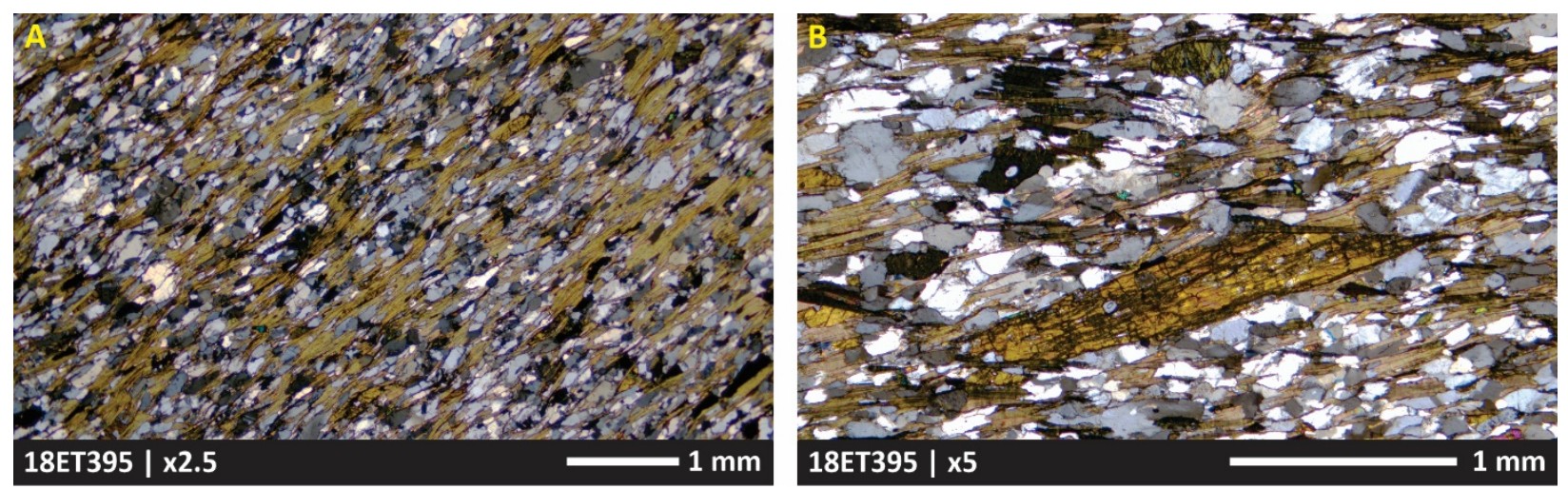

Figure 2. Transmitted light photomicrographs of orthogneiss from Lake George assemblage, A and B - crossed-polarized light. A. Fine-grained rock, with foliation highlighted by biotite. B. Closeup view of a large amphibole porphyroclast slightly oblique to the foliation.

\section{$18 A W 278$}

Quartzite; pale gray to creamy, weathering pale gray; foliated; mineral assemblage: 95 percent quartz, 5 percent muscovite, trace biotite. Subhedral quartz grains range from less than 0.1 to $2.5 \mathrm{~mm}$, and they exhibit undulose extinction. Up to 2-mm-long muscovite defines foliation, and parts 1- to 2-mm-thick bands of quartz. Trace weathering. Outcrop.

\section{Plutonic rocks}

\section{AW241 (Witherspoon porphyry)}

Granite; pale yellow fresh color, weathering pale yellow; seriate, grain size: 3 to $7 \mathrm{~mm}$; mineral assemblage: 40 percent feldspar, 30 percent quartz, 20 percent potassium feldspar, 10 percent biotite. The rock consists of large, up to 7-mm potassium feldspar, about 5-mm biotite and equant feldspar and quartz. Trace weathering.

\section{MBW295 (Witherspoon porphyry)}

Granodiorite; green, porphyritic, weakly foliated, grain size: 0.1 to $15 \mathrm{~mm}$; mineral assemblage: 70 percent albite, 15 percent potassium feldspar, 10 percent quartz, 5 percent hornblende, accessory epidote. Large, up to 15-mm plagioclase phenocrysts, subhedral to anhedral, with polysynthetic twinning, are partially sericitized (fig. 4). The sericitization is either dispersed through the crystal or focused in growth zones (fig. 4B). Up to $1 \mathrm{~mm}$, slightly perthitic potassium feldspar is sub- to anhedral (fig. $3 \mathrm{~A}$ ). The 0.5 -mm quartz is interstitial, and along with rare small microcline, hornblende, and epidote, form matrix to large feldspars. Hornblende is up to $0.5 \mathrm{~mm}$, subhedral, heavily fractured, often completely or partially replaced by actinolite. Secondary biotite forms very fine grained aggregates. Accessory epidote is associated with hornblende. The rock is porphyritic with some evidence of alteration and low-grade metamorphism. Partial weathering. The Witherspoon porphyry intrudes Fortymile River assemblage. 

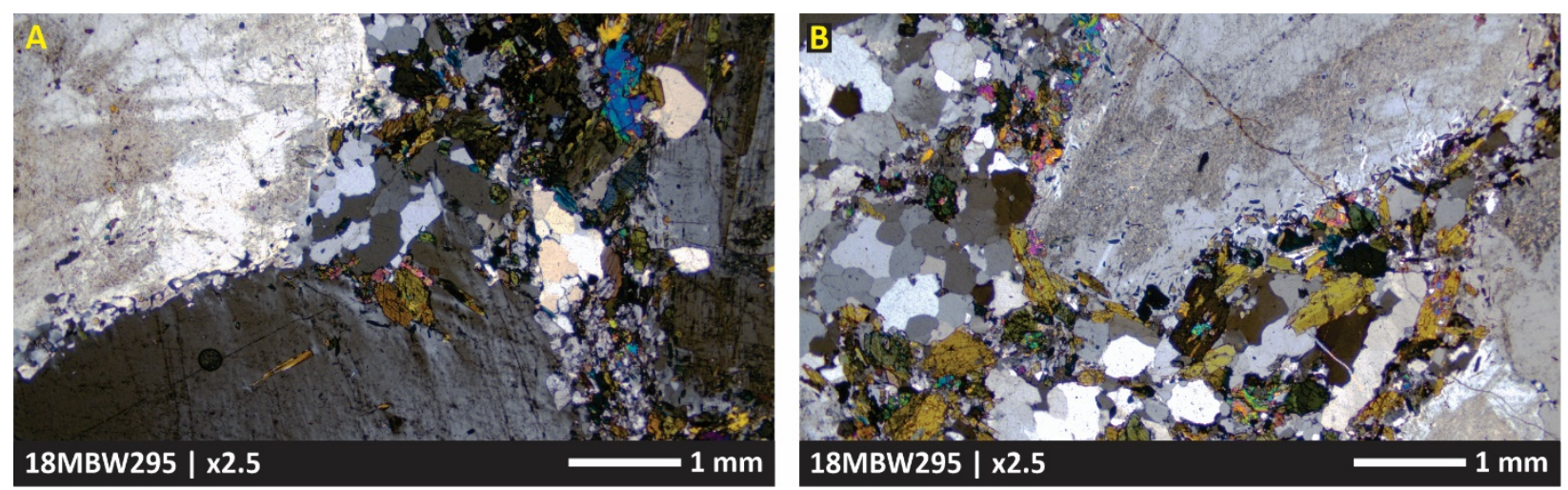

Figure 3. Transmitted-light photomicrograph of a sample from Witherspoon porphyry, cross-polarized light. A - large phenocrysts of slightly sericitized plagioclase and perthitic potassium feldspar in finer grained quartz-hornblende and feldspar matrix. B-phenocryst of plagioclase with sericite focused in crystal cones, surrounded by fine-grained hornblende, quartz, biotite, feldspar, and epidote.

\section{AW153 (Timber pluton)}

Granitoid; black and white, weathering gray, porphyritic to seriate, grain size: 5 to $15 \mathrm{~mm}$; mineral assemblage: 30 percent microcline, 30 percent plagioclase, 30 percent interstitial quartz, 10 percent biotite, and rare muscovite. Up to $15 \mathrm{~mm}$, but more commonly $5 \mathrm{~mm}$ long microcline is sub- to anhedral, with inclusions of biotite, quartz, and plagioclase (fig. $4 \mathrm{~A}$ ). Up to $2 \mathrm{~mm}$ long, sub- to anhedral plagioclase crystals have polysynthetic twinning, are sericitized, and have some myrmekite textures. Sub- to anhedral, fragmented, 0.5 $\mathrm{mm}$ long biotite crystals are often replaced by chlorite (about 30 percent of the crystals) and have opaque minerals inclusions (fig. 4B). The minerals forming this sample display minimal alteration. Trace weathering. This pluton intrudes Lake George assemblage. Outcrop.
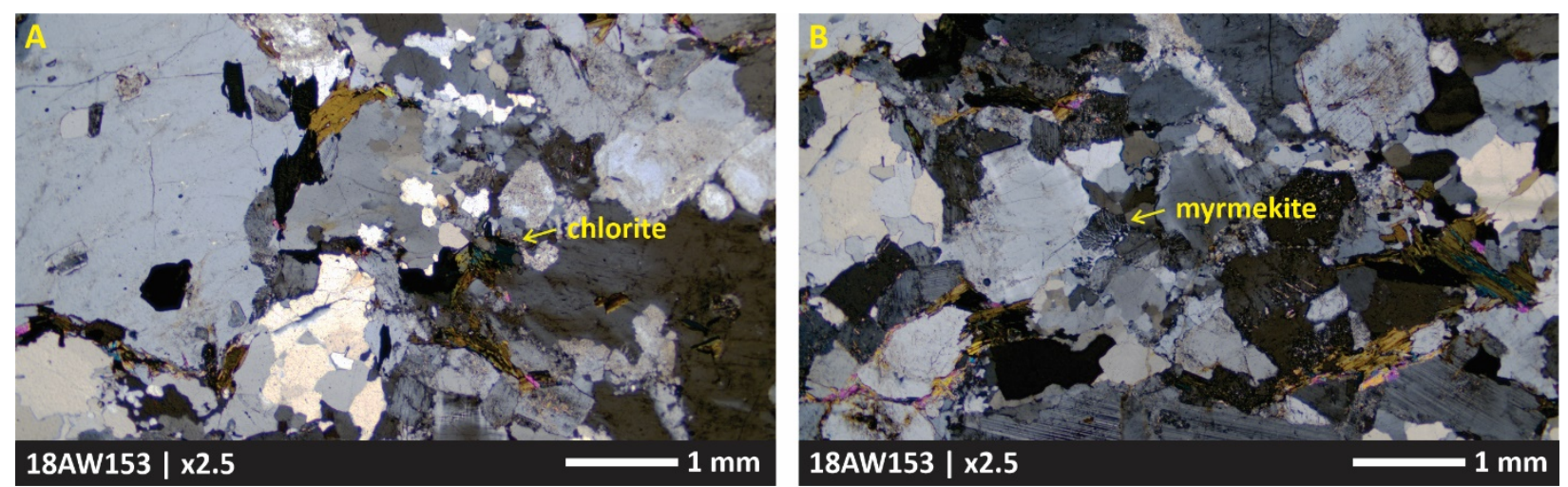

Figure 4. Transmitted light photomicrograph of a sample from Timber pluton; cross-polarized light. A - large potassium feldspar in a finer-grained martix of quartz, feldspar, and biotite, with slight chloritization. B - matrix of potassium feldspars, plagioclase with myrmekite textures, quartz, biotite, and muscovite. The feldspars are slightly chloritized.

\section{$18 E T 210$}

Garnet-bearing granite; light gray, equigranular, grain size: 1 to $3 \mathrm{~mm}$; mineral assemblage: 70 percent feldspar, 27 percent quartz, 3 percent biotite, 0.1 percent garnet. Locally pegmatitic in outcrop. Weak metamorphic fabric of aligned mica. The granite intrudes Lake George assemblage. 


\section{AW013 (Taurus granodiorite)}

Granodiorite porphyry; gray with maroon tinge, weathering tannish-brown; massive, holocrystalline, porphyritic, grain size: 1 to $10 \mathrm{~mm}$; mineral assemblage: 58 percent feldspar, 20 percent subhedral quartz, 10 percent subhedral plagioclase phenocrysts, 5 percent subhedral orthoclase phenocrysts, 4 percent subhedral hornblende phenocrysts, 2 percent subhedral biotite phenocrysts, 1 percent anhedral quartz phenocrysts. About 1-mm-long plagioclase phenocrysts display clear polysynthetic twinning, have resorbed edges, and are slightly sericitized (fig. 5A). The 5-mm orthoclase is resorbed on the edges. The mafic phenocrysts are small, no larger than $0.5 \mathrm{~mm}$, resorbed, and altered. Hornblende is altered to a fine-grained biotite-chlorite mixture and has inclusions of opaque minerals and quartz (fig. 5). In hand sample, the crystalline rock has slightly resorbed phenocrysts, often altered to sericite, chlorite, and carbonates, in a matrix of less than 0.1-mmdiameter quartz, feldspar, and opaque mineral(s). The rock looks metasomatized. The granodiorite intrudes Lake George assemblage.
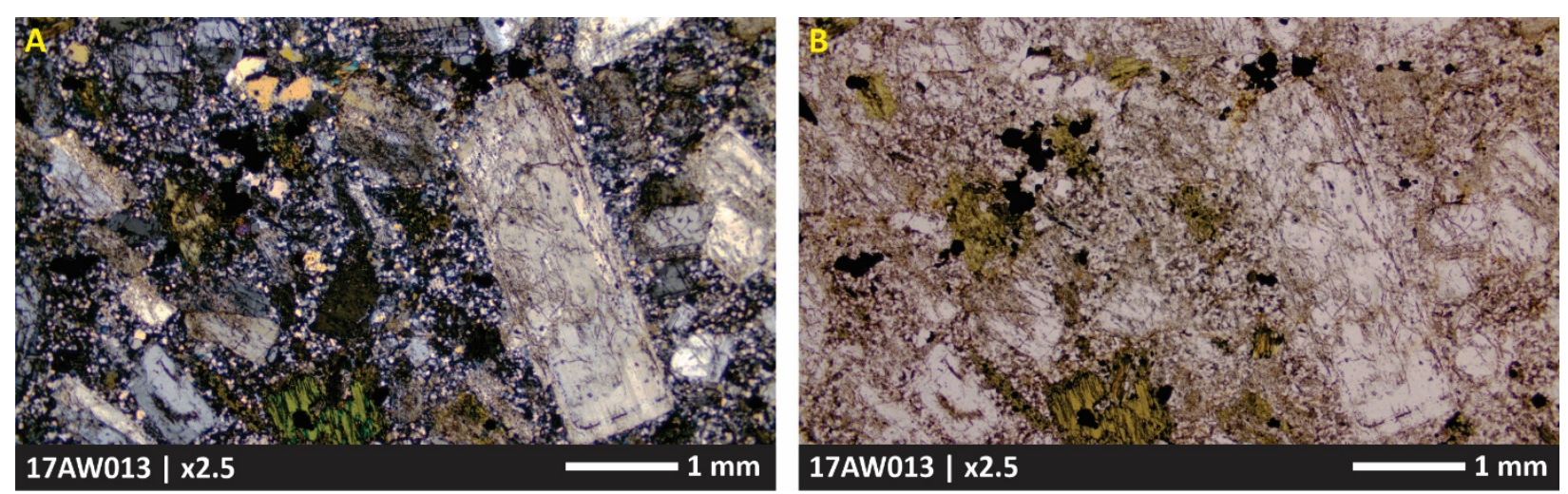

Figure 5. Transmitted-light photomicrograph of sample from Taurus granodiorite; A-cross-polarized light, B-plane light. Slightly resorbed and altered feldspar, and fragmented and chloritized hornblende phenocrysts, in altered, recrystallized, magnetite-rich, very fine-grained matrix.

\section{RN293 (Fred granite)}

Granite; pinkish-gray; jointed, porphyritic, hypidiomorphic, grain size: 1 to $7 \mathrm{~mm}$; mineral assemblage: 40 percent potassium feldspar, 30 percent plagioclase, 20 percent quartz, 5 percent biotite, accessory muscovite, zircon, opaque minerals and skeletal garnet. Sub- to anhedral potassium feldspars are on average about 1-mm long but rare, 7-mm-long phenocrysts form about 2 percent of the rock. The feldspars have minimal sericitization, and myrmekite resorption (no more than 0.5 percent of the crystals; fig. $6 \mathrm{~A}$ ). Up to 0.5-mm-long, sub- to anhedral plagioclase has polysynthetic twinning. Large phenocrysts of potassic feldspar (no zonation) in a matrix of feldspar, 3-mm-long quartz, and 0.5-mm-long biotite (fig. 6A). About 50 percent of the biotite has ilmenite and other opaque inclusions, and some have zircon inclusions. Some large quartz present in zones of larger feldspar and quartz could perhaps represent lithic fragments(?). This sample is similar to 18RN291, but with subtle fabric, which is likely the result of minor deformation near the margin of the pluton. This granite intrudes Lake George assemblage. Trace weathering.

This sample is a composite of 18RN293, 18RN294, 18RN296, and 18RN300 samples collected over 0.8mile transect. 

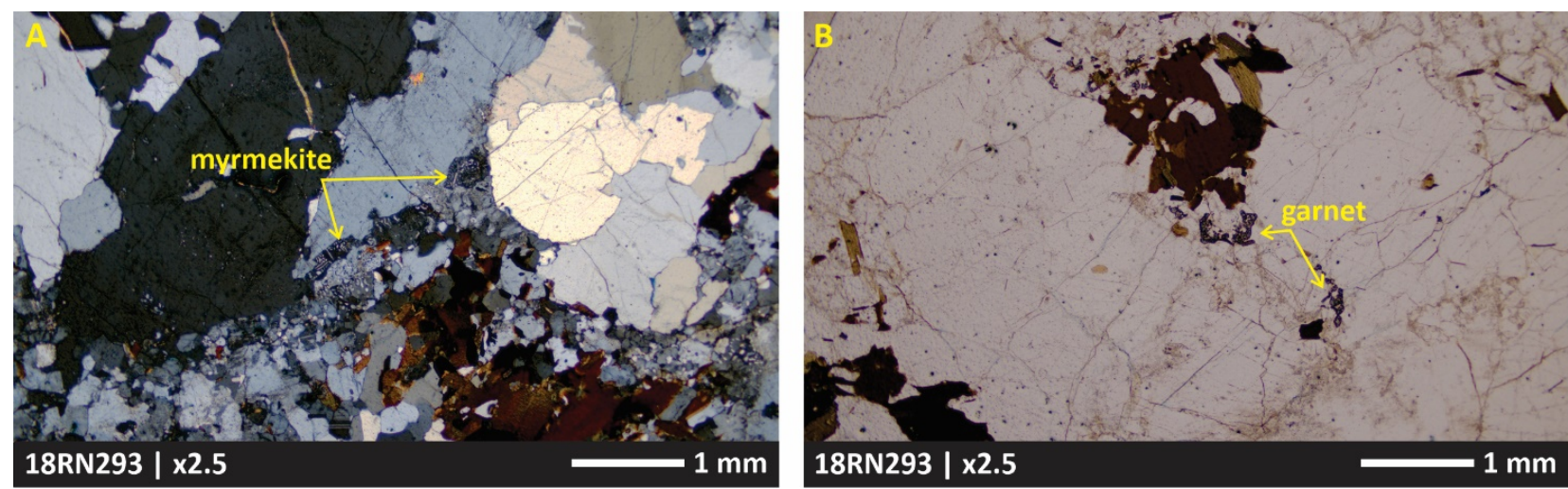

Figure 6. Transmitted-light photomicrograph of a sample from Fred granite, A -cross-polarized light, B - plane light. Large potassium feldspar in a matrix of finer-grained plagioclase, quartz and biotite with accessory skeletal garnet. No visible foliation.

\section{Sedimentary rocks}

\section{$18 E T 382$}

Sandstone: tan; bedded, moderately sorted, angular, grain size: 0.5 to $8 \mathrm{~mm}$. Moderately indurated sandstone ranging from medium to very coarse-grained; apparently bedded. Clasts are dominated by quartz, 1 percent feldspar, and 1 percent white mica.

\section{$18 E T 413$}

Conglomerate: About 2-cm-long, but up to 20-cm, elongated, subrounded clasts of quartzite, semischist, feldspar, and quartz in a matrix of quartz, muscovite, biotite, and some feldspar (fig. 7). Station Notes: "From uphill: Abundant rounded cobbles to boulders, plus lithified pebble conglomerate."
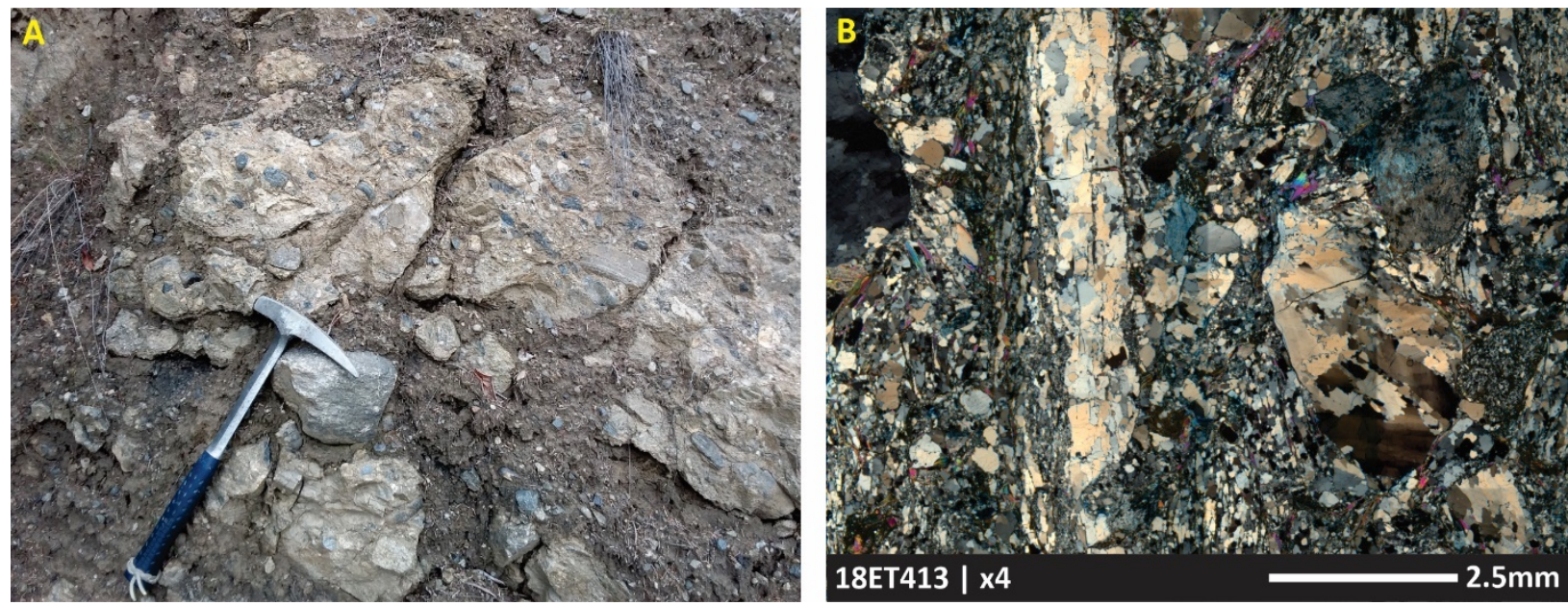

Figure 7. Photographs of a sample from Cretaceous conglomerate; A - outcrop of conglomerate showing lightly indurated rock with clasts ranging from about $1 \mathrm{~cm}$ to $20 \mathrm{~cm}$ in diameter. B - transmitted-light photomicrograph under cross-polarized light showing quartzite clasts. 


\section{RESULTS ANDDISCUSSION}

A summary of all interpreted $\mathrm{U}-\mathrm{Pb}$ ages is included in Table 2, with uncertainty for all ages, isotope ratios, and reported $2 \sigma$ level. As outlined above, a concordance filter was used to eliminate grains that were either heterogeneous or experienced $\mathrm{Pb}$ loss after formation. Filtered grains were not included in the final interpreted ages reported below.

\section{Metamorphic rocks}

An amphibolite sample from Lake George assemblage, 18AW074, yielded an Early Mississippian age of 351.5 $\pm 4.3 \mathrm{Ma}$ (fig. 8A), and a metagabbro (18TJN213) from an ultramafic complex within the Lake George assemblage yielded a Late Devonian age of 360.5 $\pm 3.6 \mathrm{Ma}$ (fig. 8B). Both samples yielded single zircon-age populations with minimal inheritance or $\mathrm{Pb}$ loss. Both ages are interpreted to represent crystallization of the mafic protoliths.

Lake George Assemblage
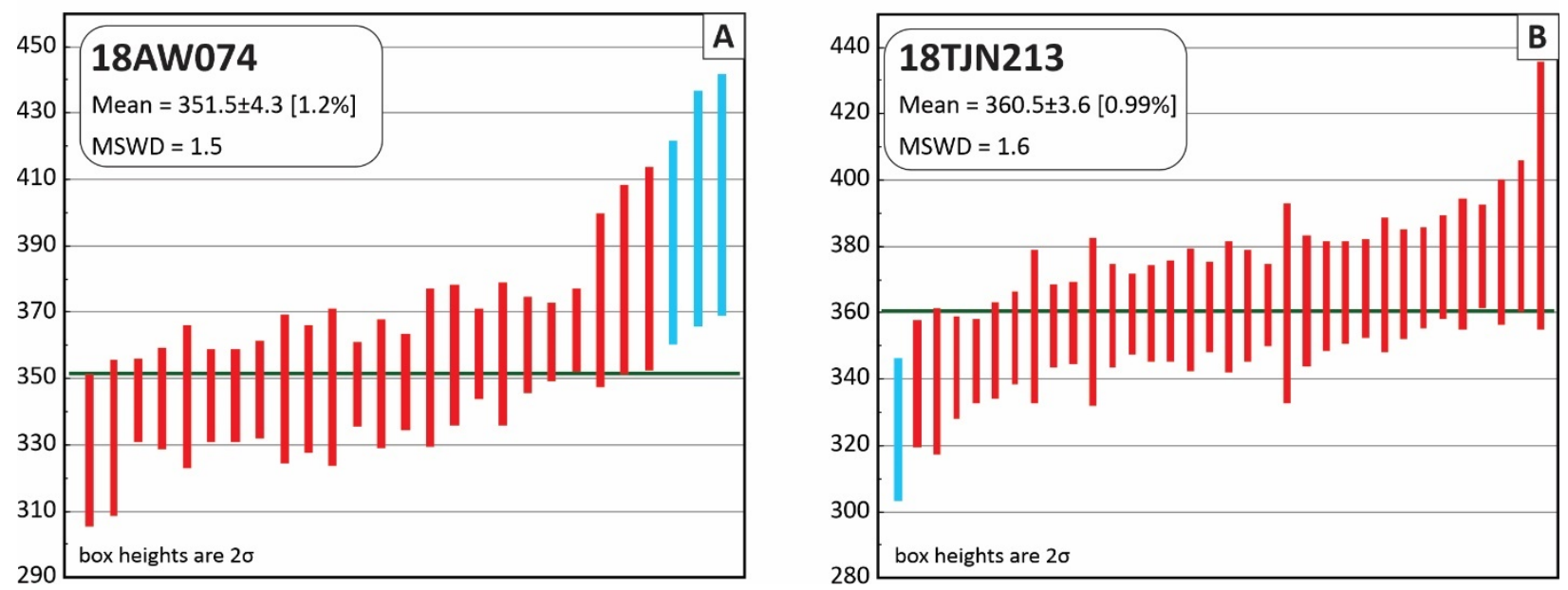

Figure 8. Plots of measured zircon U-Pb ages (vertical axes) for main populations for samples from Lake George assemblage. Red bars indicate zircon ages, at $2 \sigma$ bar height, that contribute to weighted means. Blue bars indicate zircon analyses that were excluded from the weighted mean (that is, omitted as statistical outliers).

Amphibolite from Fortymile River assemblage (18JEA011; fig. 9A) yielded two distinctive zircon populations, with ages of Mississippian and latest Permian to earliest Triassic. We believe the Mississippian age of 336.9 $\pm 3.8 \mathrm{Ma}$ represents the initial crystallization of the mafic protolith, whereas the Permian to Triassic grains represent recrystallization and/or $\mathrm{Pb}$ loss during a younger metamorphic event.

Felsic orthogneiss from the Fortymile River assemblage (18ET395; fig. 9B) yielded a Mississippian age of $341.1 \pm 2.3 \mathrm{Ma}$ that we interpret to be a protolith age. The sample also contained some younger Late Triassic to Early Jurassic grains that likely record recrystallization and/or Pb loss during a younger metamorphic event.

During field investigations conducted the summer of 2017 by the DGGS, the quartzite sample 17ET027 (fig. 9C, D) was interpreted as a Lake George assemblage metasedimentary unit, and the Archean and Proterozoic detrital age populations are consistent with Lake George assemblage metasedimentary rocks (fig. 9C; Dusel-Bacon and others, 2017). However, the presence of a distinct Permian population requires that the 
sample is the Fortymile River assemblage. The Permian grains have low Th/U ratios suggesting that they are metamorphic, and they likely formed during metamorphism associated with the Klondike orogeny (Beranek and Mortensen, 2011), observed only in the allochthonous assemblages. Similarly, quartzite sample 18AW278 from the Fortymile River assemblage (fig. 9E, F) also contains a distinct Permian population with low Th/U ratios together with a broad detrital spectrum of Proterozoic and Paleozoic ages. 
Fortymile Assemblage
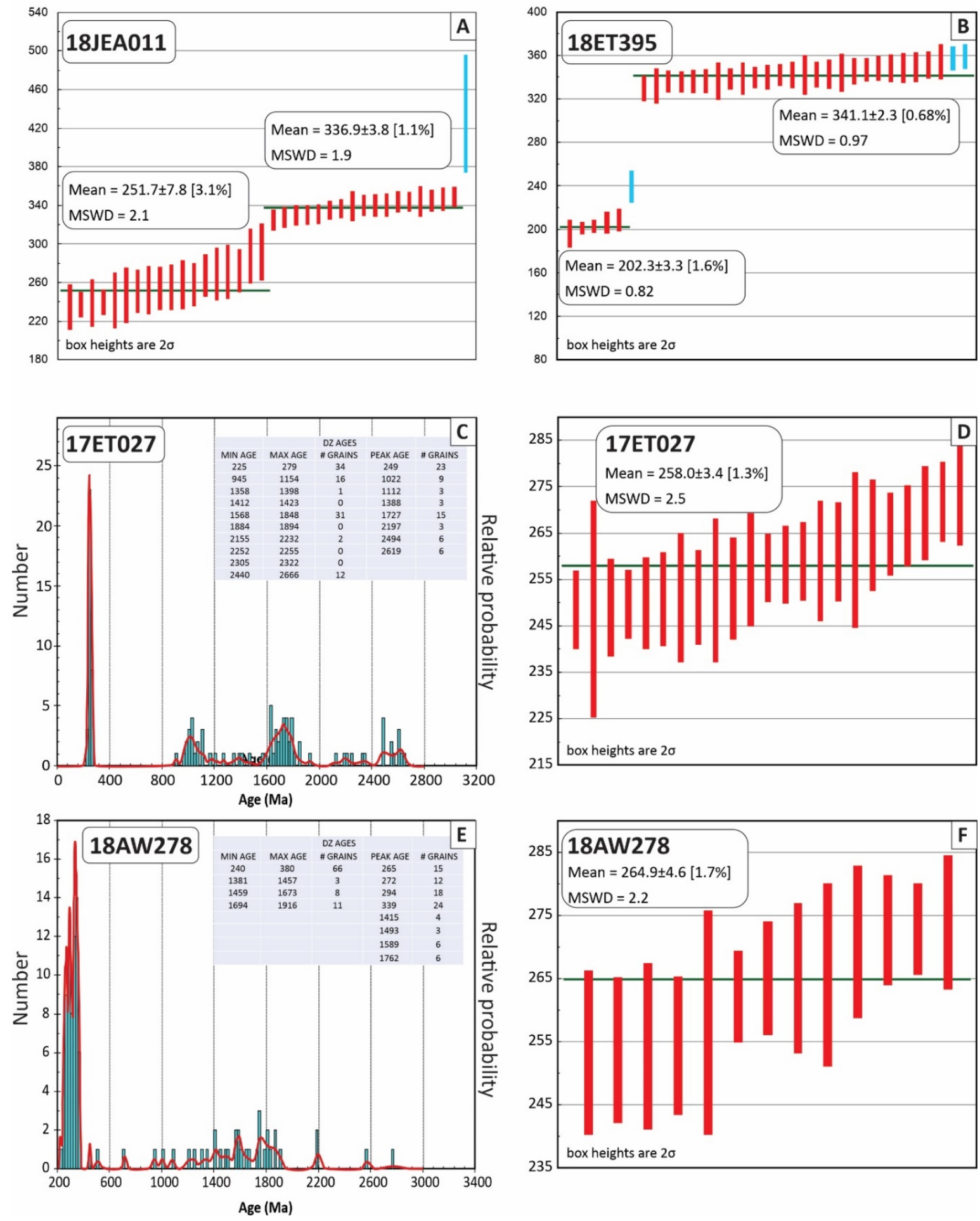

Figure 9. Plots of measured zircon U-Pb ages for main populations for samples from Fortymile River assemblage. Red bars indicate zircon ages, at $2 \sigma$ bar height, that contribute to weighted means. Blue bars indicate zircon analyses that were excluded from the weighted mean (that is, omitted as statistical outliers). The inset tables labeled "DZ ages" show statistical age ranges and age populations for detrital zircon grains that were calculated using the AgePick macro developed by G. Gehrels for MS Excel (Gehrels and others, 2008). 


\section{Intrusive suites}

Two samples were collected from the Witherspoon pluton (18AW241 and 18MBW295; fig. 10A and B, respectively). Both samples returned Late Triassic ages of 206.2 \pm 2.6 and 203.7 $\pm 1.6 \mathrm{Ma}$, respectively, suggesting that the pluton belongs to the Taylor Mountain suite (Aleinikoff and others, 1981; Werdon and others, 2001).

Two samples of Cretaceous granite were analyzed, one from Timber pluton (18AW153; fig. 10C) and one from a granite pluton on the Alaska-Yukon border (18ET210; fig. 10D). They returned magmatic ages of

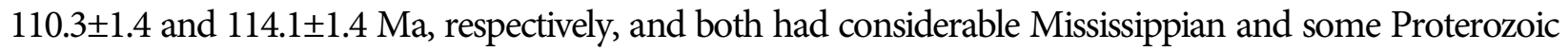
zircon inheritance.

A sample from magnetic granodiorite in the Taurus area (17AW013; fig. 10E) yielded a Late Cretaceous age of 71.0 $\pm 1.1 \mathrm{Ma}$. This sample had a few inherited grains with ages ranging from Mississippian to Jurassic.

A sample from Fred granite (18RN293; fig. 10F) yielded a consistent Mississippian population of zircons with a weighted average age of $353.1 \pm 2.7 \mathrm{Ma}$. This population can be interpreted either as the crystallization age of this pluton or inheritance. The pluton itself is only slightly foliated at the edge, and the core is an unfoliated granitic body. The similarity of the chemical composition of this pluton to other Cretaceous plutons, and the apparent lack of foliation or mineral recrystallization, suggest the latter interpretation of the age to be more plausible but does not exclude the possibility of this pluton being an unmetamorphosed remnant of the Mississippian orthogneisses common in the region. 
Triassic to Cretaceous intrusive rocks
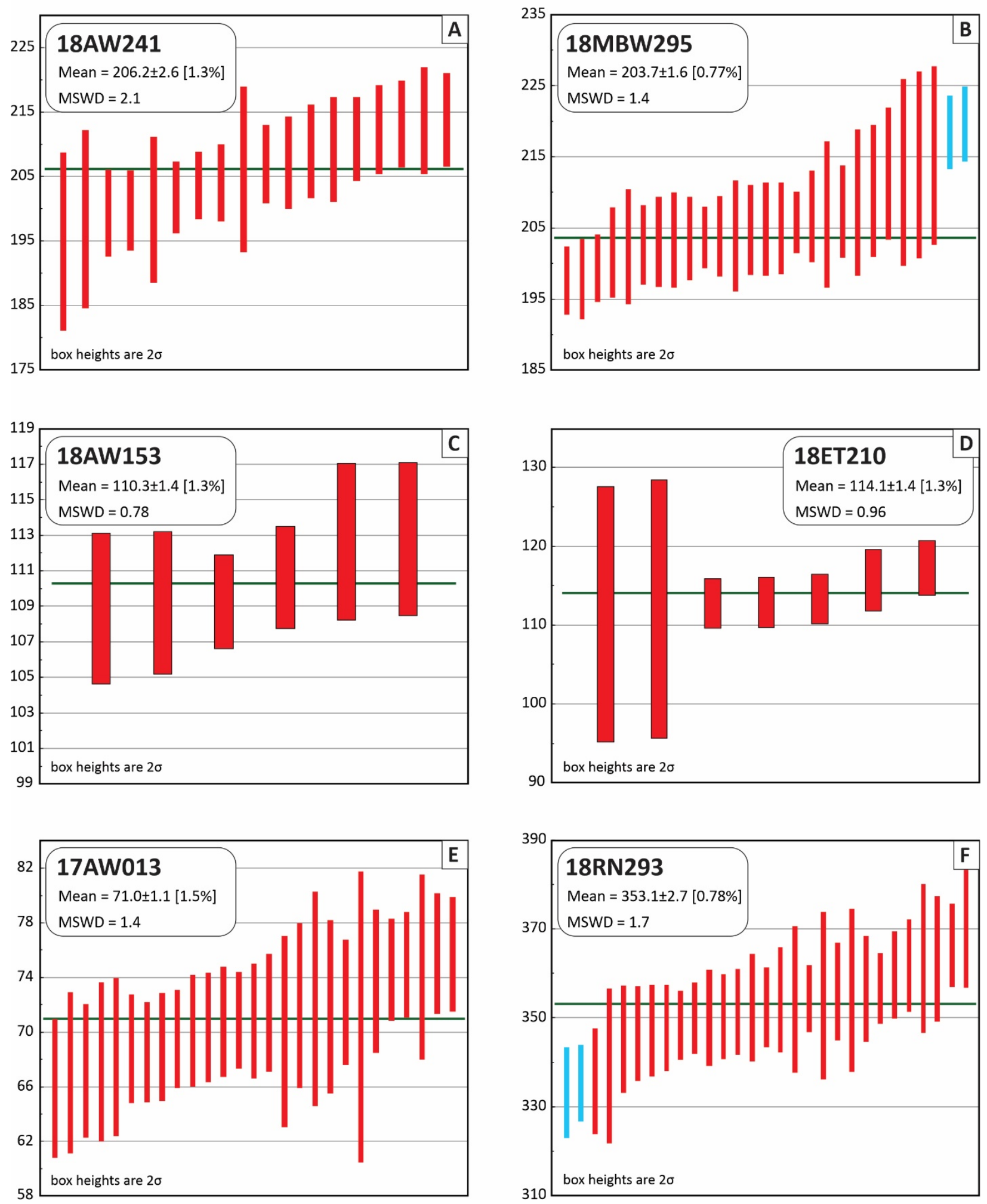

Figure 10. Plots of measured zircon U-Pb ages for main populations for intrusive suites samples. Red bars indicate zircon ages, at $2 \sigma$ bar height, that contribute to weighted means. Blue bars indicate zircon analyses that were excluded from the weighted mean (that is, omitted as statistical outliers). 


\section{Cretaceous sandstone and conglomerate}

Two samples from two different conglomerate outcrops were analyzed for detrital zircon ages. One sandstone sample was collected north of VABM Lode (18ET382; fig. 11A, B), and one conglomerate sample was collected from the western edge of the map area (18ET413; fig. 11C, D). Both conglomerates have a middle Cretaceous youngest-zircon population, suggesting that they are likely correlative with the Albian Indian River Formation documented in western Yukon (Lowey and Hills, 1988).

\section{Cretaceous conglomerates}
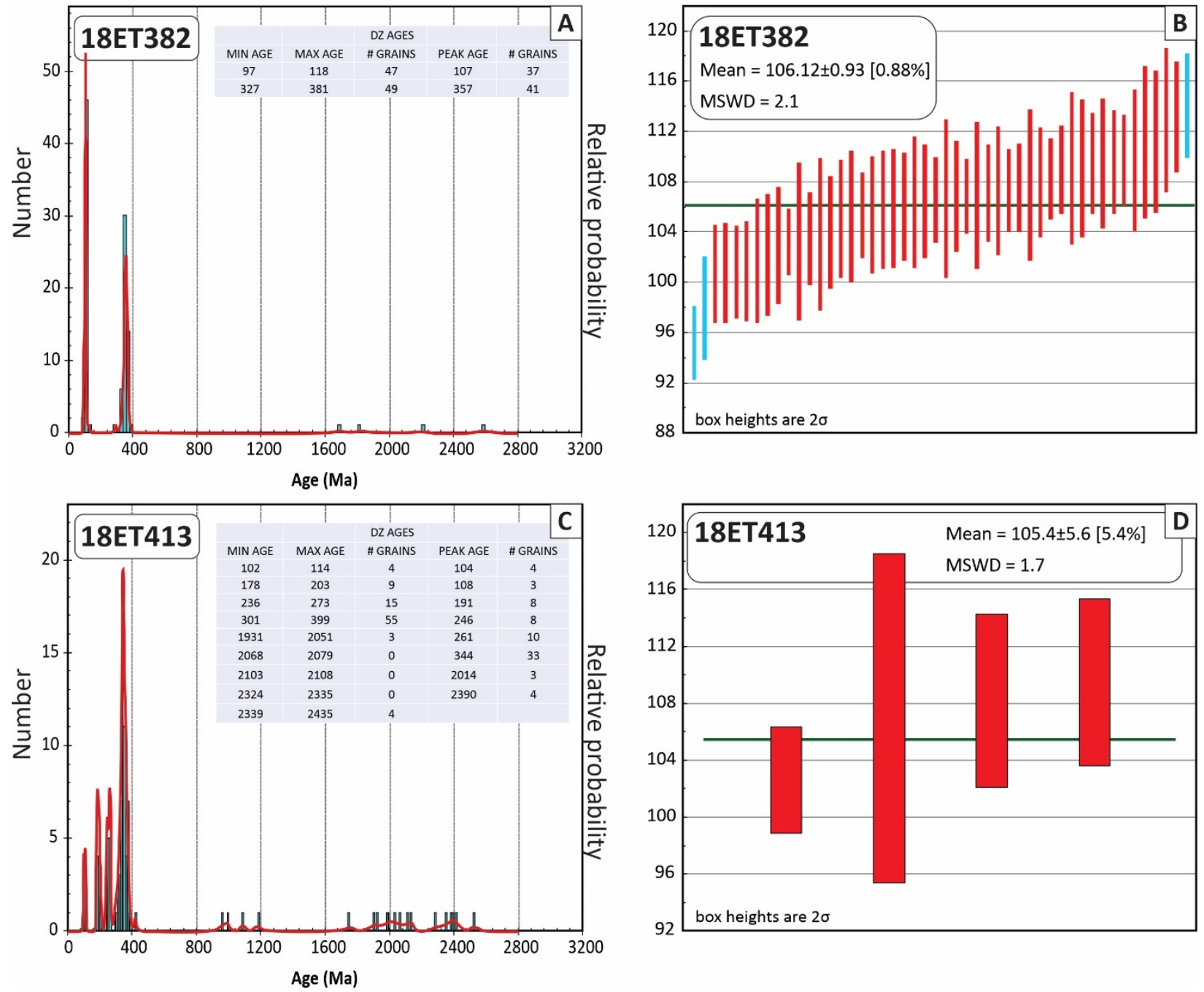

Figure 11. Plots of measured zircon U-Pb ages for main populations for sandstone and conglomerate samples. Red bars indicate zircon ages, at $2 \sigma$ bar height, that contribute to weighted means. Blue bars indicate zircon analyses that were excluded from the weighted mean (that is, omitted as statistical outliers). 
Table 2. Summary of the weighted-mean age of main and inheritance populations of analyzed zircon samples.

\begin{tabular}{|c|c|c|c|c|c|c|}
\hline & Sample & Lithology & Longitude & Latitude & Comment & $\begin{array}{c}{ }^{238} \mathrm{U} /{ }^{206} \mathrm{~Pb} \text { best } \\
\text { age [Ma] }\end{array}$ \\
\hline \multirow{2}{*}{ Lake George } & 18AW074 & amphibolite & -141.0233 & 63.7456 & main crystallization & $351.5 \pm 4.3$ \\
\hline & 18TJN213 & metagabbro & -141.1148 & 63.7265 & main crystallization & $360.5 \pm 3.6$ \\
\hline \multirow{6}{*}{ Fortymile } & 18JEA011 & amphibolite & -141.0244 & 63.9407 & main crystallization & $336.9 \pm 3.8$ \\
\hline & & & & & metamorphic overprint & $251.7 \pm 7.8$ \\
\hline & 18ET395 & orthogneiss & -141.3246 & 63.9164 & main crystallization & $341.1 \pm 2.3$ \\
\hline & & & & & metamorphic overprint & $202.3 \pm 3.3$ \\
\hline & 17ET027 & schist to gneiss & -141.0795 & 63.8471 & metamorphic overprint & $258.0 \pm 3.4$ \\
\hline & 18AW278 & quartzite & -141.4987 & 63.9853 & metamorphic overprint & $264.9 \pm 4.6$ \\
\hline \multirow{6}{*}{ Intrusive suites } & 18RN293 & granite & -141.1428 & 63.7593 & all inheritance? & $353.1 \pm 2.7$ \\
\hline & 18AW241 & granite & -141.2947 & 63.9363 & crystallization & $206.2 \pm 2.6$ \\
\hline & 18MBW295 & granodiorite & -141.2507 & 63.9529 & crystallization & $203.7 \pm 1.6$ \\
\hline & 18AW153 & granite & -141.1419 & 63.6213 & crystallization & $110.3 \pm 1.4$ \\
\hline & $18 \mathrm{ET} 210$ & granite & -141.0744 & 63.8189 & crystallization & $114.1 \pm 1.4$ \\
\hline & 17AW013 & granodiorite & -141.262 & 63.6494 & crystallization & $71.0 \pm 1.1$ \\
\hline \multirow{2}{*}{$\begin{array}{c}\text { Cretaceous } \\
\text { conglomerates }\end{array}$} & $18 \mathrm{ET} 382$ & sandstone & -141.2454 & 63.9198 & youngest population & $106.12 \pm 0.93$ \\
\hline & $18 \mathrm{ET} 413$ & conglomerate & -141.6491 & 63.8795 & youngest population & $105.4 \pm 5.6$ \\
\hline
\end{tabular}

\section{ACKNOWLEDGMENTS}

The Northeast Tanacross project was funded by Alaska State General Funds and U.S Geological Survey STATEMAP Award No. G18AC00137. The authors would like to thank Dr. Sean Regan for providing insightful review comments for this PIR. Any use of trade, firm, or product names is for descriptive purposes only and does not imply endorsement by the U.S. Government. 


\section{REFERENCES}

Aleinikoff, J.N., Dusel-Bacon, Cynthia, and Foster, H.L., 1986, Geochronology of augen gneiss and related rocks, Yukon-Tanana terrane, east-central Alaska: Geological Society of America Bulletin, v. 97, n. 5, p. 626-637.

Aleinikoff, J.N., Dusel-Bacon, Cynthia, Foster, H.L., and Futa, K., 1981, Proterozoic zircon from augen gneiss, Yukon-Tanana Upland, east-central Alaska: Geology, v. 9, p. 469-473.

Beranek, L.P., and Mortensen, J.K., 2011, The timing and provenance record of the Late Permian Klondike orogeny in northwestern Canada and arc-continent collision along western North America: Tectonics, v. 30, n. 5, p. 1-23.

Black, L.P., Kamo, S.L., Allen, C.M., Davis, D.W., Aleinikoff, J.N., Valley, J.W., Mundil, R., Campbell, I.H., Korsch, R.J., Williams, I.S., and Foudoulis, C., 2004, Improved ${ }^{206} \mathrm{~Pb} /{ }^{238} \mathrm{U}$ microprobe geochronology by the monitoring of a trace-element-related matrix effect; SHRIMP, ID-TIMS, ELA-ICP-MS and oxygen isotope documentation for a series of zircon standards: Chemical Geology, v. 205, n. 1-2, p. 115-140.

Chang, Zhaoshan, Vervoort, J.D., McClelland, W.C., and Knaack, Charles, 2006, U-Pb dating of zircon by LA-ICP-MS: Geochemistry, Geophysics, Geosystems, v. 7, n. 5, 14p.

Donelick, R.A., O'Sullivan, P.B., and Ketcham, R.A., 2005, Apatite fission-track analysis: Reviews in Mineralogy and Geochemistry, v. 58, p. 49-94.

Dusel-Bacon, Cynthia, Hopkins, M.J., Mortensen, J.K., Dashevsky, S.S., Bressler, J.R., and Day, W.C., 2006, Paleozoic tectonic and metallogenic evolution of the pericratonic rocks of east-central Alaska and adjacent Yukon: in Colpron, Maurice, and Nelson J.L., eds., Paleozoic Evolution and Metallogeny of Pericratonic Terranes at the Ancient Pacific Margin of North America, Canadian and Alaskan Cordillera: Geological Association of Canada Special Paper 45, p. 25-74.

Dusel-Bacon, Cynthia, Holm-Denoma, C.S., Jones, J.V. III, Aleinikoff, J.N., and Mortensen, J.K., 2017,

Detrital zircon geochronology of quartzose metasedimentary rocks from parautochthonous North America, east-central Alaska: Lithosphere, v. 9, no. 6, p. 927-952; GSA Data Repository Item 2017332.

https://doi.org/10.1130/L672.1

Foster, H.L., 1970, Reconnaissance geologic map of the Tanacross quadrangle, Alaska: U.S. Geological Survey Miscellaneous Geologic Investigations Map 593, 1 sheet, scale 1:250,000.

Gehrels, G., 2009, Age Pick program, Excel 2003 macro. https:/drive.google.com/file/d/0B9ezu34P5h8eNWRkMGZkNTgtZDdhOC00OGZkLTkxNjUtYzY5 M2UzYjU1ZmVi/view?hl=en_US.

Gehrels, G.E., Valencia, V.A., and Ruiz, Joaquin, 2008, Enhanced precision, accuracy, efficiency, and spatial resolution of $\mathrm{U}-\mathrm{Pb}$ ages by laser ablation-multicollector-inductively coupled plasma-mass spectrometry: Geochemistry, Geophysics, Geosystems, v. 9, n. 3, p. 1-13.

Kuiper, K.F., Deino, Alan, Hilgen, F.J., Krijgsman, Wout, Renne, P.R., and Wijbrans, J.R., 2008, Synchronizing rock clocks of Earth history: Science, v. 320, n. 5,875, p. 500-504.

Lanphere, M.A., and Baadsgaard, H., 2001, Precise K-Ar, ${ }^{40} \mathrm{Ar} /{ }^{39} \mathrm{Ar}, \mathrm{Rb}-\mathrm{Sr}$ and U-Pb mineral ages from the 27.5 Ma Fish Canyon Tuff reference standard: Chemical Geology, v. 175, p. 653-671.

Lowey, G.W., and Hills, L. V., 1988, Lithofacies, petrography, and environments of deposition, Tantalus 
Formation (Lower Cretaceous) Indian River area, west-central Yukon: Bulletin of Canadian Petroleum Geology, v. 36, n. 3, p. 296-310.

Ludwig, K.R., 2012, User's Manual for Isoplot 3.75, A Geochronological Toolkit for Microsoft Excel: Berkeley Geochronology Centre Special Publication no. 5 (rev. January 30, 2012), 75 p., Berkeley, CA, USA.

Naibert, T.J., Benowitz, J.A., Wypych, Alicja, Sicard, K.R., and Twelker, Evan, 2018, ${ }^{40} \mathrm{Ar} /{ }^{39} \mathrm{Ar}$ data from the Tanacross D-1 and D-2, Big Delta B-4 and B-5, and Mount Hayes A-6 quadrangles, Alaska: Alaska Division of Geological \& Geophysical Surveys Raw Data File 2018-3, 15 p.

Nemchin, A.A., and Cawood, P.A., 2005, Discordance of the U-Pb system in detrital zircons: Implication for provenance studies of sedimentary rocks: Sedimentary Geology, v. 182, p. 143162. https://doi.org/10.1016/j.sedgeo.2005.07.011

Paces, J.B., and Miller, J.D., 1993, Precise U-Pb ages of Duluth Complex and related mafic intrusions, northeastern Minnesota: Geochronological insights to physical, petrogenic, paleomagnetic, and tectonomagmatic processes associated with the 1.1 Ga Midcontinent Rift System: Journal of Geophysical Research, v. 98, n. B8, p. 13,997-14,013.

Paton, C., Woodhead, J.D., Hellstrom, J.C., Hergt, J.M., Greig, Alan, and Maas, Roland, 2010, Improved laser ablation $\mathrm{U}-\mathrm{Pb}$ zircon geochronology through robust downhole fractionation correction: Geochemistry, Geophysics, Geosystems, v. 11, n. 3, 36 p.

Renne, P.R., Swisher, C.C., Deino, A.L., Karner, D.B., Owens, T.L., and DePaolo, D.J., 1998, No intercalibration of standards, absolute ages and uncertainties in ${ }^{40} \mathrm{Ar} /{ }^{39} \mathrm{Ar}$ dating: Chemical Geology, v. 45, p. 117-152.

Stacey, J.S., and Kramers, J.D., 1975, Approximation of terrestrial lead isotope evolution by a two-stage model: Earth and Planetary Science Letters, v. 26, n. 2, p. 207-221.

Steiger, R.H., and Jäger, E., 1977, Subcommission on geochronology: Convention on the use of decay constants in geo- and cosmochronology: Earth and Planetary Science Letters, v. 36, n. 3, p. 359-362.

Todd, Erin, Wypych, Alicja, and Kylander-Clark, Andrew, 2019, U-Pb and Lu-Hf isotope, age, and trace element data from zircon separates from the Tanacross D-1, and parts of D-2, C-1, and C-2 quadrangles: Alaska Division of Geological \& Geophysical Surveys Raw Data File 2019-5, 10 p.

Werdon, M.B., Newberry, R.J., Szumigala, D.J., and Pinney, D.S., 2001, Geologic map of the Eagle A-2 Quadrangle, Fortymile Mining District, Alaska: Alaska Division of Geological \& Geophysical Surveys Preliminary Interpretive Report 2001-3A, 1 sheet, scale 1:63,360.

Zhang, Ming, Ewing, R.C., Boatner, L.A., Salje, E.K.H., Weber, W.J., Daniel, Philippe, Zhang, Yanwen, and Farnan, Ian, 2009, Pb+ irradiation of synthetic zircon (ZrSi04): Infrared spectroscopic investigationReply: American Mineralogist, v. 94, n. 5-6, p. 856-858. 